\title{
ANALISIS ARSITEKTUR ENTERPRISE MENGGUNAKAN TOGAF ADM VERSI 9.2 PADA PT. INDUSTRI TELEKOMUNIKASI INDONESIA (PERSERO)
}

\author{
Galang Airlangga Pratama ${ }^{1}$, Khaerul Manaf ${ }^{2}$, SW Pitara ${ }^{3}$ \\ 1, 2,3 Prodi Sistem Informasi, Fakultas Teknik, Universitas Sangga Buana \\ ${ }^{1}$ korespondensi : galangairlangga1@gmail.com
}

\begin{abstract}
The rapid development of information technology and changes in the organizational environment force companies to adapt in order to be able to maintain the existence of the organization in the long term, so that a model is needed in planning, designing and managing the organization. information systems and information technology to help optimize. PT Industri Telekomunikasi Indonesia (Persero) also known as PT. INTI (Persero) focuses on business lines in manufacturing and assembly, managed services, digital services, and system integrators.PT. INTI (Persero) has implemented information systems and information technology to help run existing business processes, but there are problems where the application creation is still functional, there are different applications that have the same features with different databases and there are applications that are no longer used after the implementation stage. Therefore, an enterprise architecture is needed to achieve alignment between the IS/IT strategy with the business strategy and to avoid applications that focus on functional organizations only.In this case study, the author chooses to use the TOGAF framework in the analysis of business architecture, including the introduction phase, architectural vision, business architecture, information systems architecture, and technology architecture. and produce a master architecture plan TOGAF ADM, with the hope that this enterprise architecture design can help PT. INTI (Persero) in the development and design of information systems and information technology in the future.
\end{abstract}

Keywords: Enterprise Architecture, TOGAF ADM, PT. INTI

\begin{abstract}
ABSTRAK
Pesatnya perkembangan teknologi informasi dan perubahan lingkungan organisasi memaksa perusahaan untuk beradaptasi agar mampu mempertahankan eksistensi organisasi dalam jangka panjang, sehingga diperlukan suatu model dalam perencanaan, perancangan dan pengelolaan organisasi. sistem informasi dan teknologi informasi untuk membantu mengoptimalkan. PT Industri Telekomunikasi Indonesia (Persero) juga dikenal sebagai PT. INTI (Persero) fokus pada lini bisnis di bidang manufaktur dan perakitan, layanan terkelola, layanan digital, dan integrator sistem. PT. INTI (Persero) telah menerapkan sistem informasi dan teknologi informasi untuk membantu jalannya proses bisnis yang ada, tetapi terdapat masalah di mana pembuatan aplikasi masih bersifat fungsional, terdapat aplikasi berbeda yang memiliki fitur sama dengan database berbeda dan terdapat aplikasi yang tidak digunakan lagi setelah tahap implementasi oleh sebab itu dibutuhkan arsitektur enterprise agar terwujudnya keselarasan antara strategi SI/TI dengan strategi bisnis dan untuk menghindari aplikasi yang berfokus ke organisasi fungsional saja.Dalam studi kasus ini, penulis memilih untuk menggunakan framework TOGAF dalam analisis arsitektur bisnis, meliputi fase pendahuluan, visi arsitektur, arsitektur bisnis, arsitektur sistem informasi, dan arsitektur teknologi. dan menghasilkan master architecture plan TOGAF ADM, dengan harapan rancangan enterprise architecture ini dapat membantu PT. INTI (Persero) dalam pengembangan dan perancangan sistem informasi dan teknologi informasi di masa yang akan datang.
\end{abstract}

Kata Kunci: Arsitektur Enterprise, TOGAF ADM, PT. INTI

\section{PENDAHULUAN}

Saat ini perkembangan teknologi informasi dan komunikasi sangat pesat, diperlukan adanya teknologi untuk mendukung berjalannya proses bisnis sebagai solusi untuk meningkatkan kualitas dan daya saing perusahaan karena semakin besar perusahaan maka semakin besar proses bisnis dan kebutuhan fungsional, terutama data, aplikasi dan teknologi. semakin berkembang.

Dengan perkembangan teknologi informasi yang cepat serta perubahan lingkungan 
organisasi menuntut perusahaan untuk melakukan perubahan untuk menjaga kelangsungan hidup organisasi dalam jangka panjang, maka dibutuhkan sebuah pola dalam merencanakan, merancang dan mengelola sistem informasi dan teknologi informasi agar dapat membantu secara optimal. Oleh karena itu dibutuhkan arsitektur enterprise untuk dijadikan sebagai kerangka kerja untuk pengembangan sistem informasi dan teknologi informasi ke depannya yang sesuai dengan proses bisnis yang ada.

Arsitektur perusahaan adalah cara untuk menggambarkan model operasi bisnis yang mencakup aspek perencanaan bisnis, operasi bisnis, otomatisasi, dan dukungan infrastruktur TI. Enterprise Architecture terdiri dari empat komponen/area utama: Enterprise Architecture, Information Architecture, Technology Architecture dan Application Architecture[1]. PT Industri Telekomunikasi Indonesia (Persero) atau dikenal PT. INTI (Persero) adalah salah satu BUMN di Indonesia, resmi berdiri pada 30 Desember 1974, PT INTI fokus pada lini bisnis di bidang Manufacture and Assembly, Managed Service, Digital Service dan System Integrator. Untuk mendukung bisnisnya, PT INTI (Persero) juga menjalankan INTI Smart Industrial Park, tempat produksi seluas delapan hektar di Jalan Moch Toha No 225 yang menghasilkan perangkat telekomunikasi dan elektronik.

PT. INTI (Persero) telah menerapkan sistem informasi dan teknologi informasi untuk membantu jalannya proses bisnis yang ada, tetapi terdapat masalah di mana pembuatan aplikasi masih bersifat fungsional, terdapat aplikasi berbeda yang memiliki fitur sama dengan database berbeda dan terdapat aplikasi yang tidak digunakan lagi setelah tahap implementasi oleh sebab itu dibutuhkan arsitektur enterprise agar terwujudnya keselarasan antara strategi SI/TI dengan strategi bisnis dan untuk menghindari aplikasi yang berfokus ke organisasi fungsional saja. Arsitektur enterprise menghasilkan jalan yang dapat memberikan pedoman untuk investasi masa depan dan dapat membantu menyelesaikan kesenjangan antara fungsi bisnis dan SI/TI dalam organisasi [1].

Untuk memudahkan analisis arsitektur enterprise, kali ini penulis memutuskan untuk menggunakan framework TOGAF dalam analisis arsitektur enterprise. TOGAF adalah framework dan metode yang diterima secara luas dalam sistem informasi pengembangan arsitektur enterprise yang disebut Architecture Development Method (ADM) [1].

Tujuan dalam penelitian ini, yaitu menghasilkan sebuah analisis arsitektur enterprise untuk menyelaraskan strategi bisnis dengan strategi SI/TI pada PT. INTI (Persero).

\section{TINJAUAN PUSTAKA}

\section{Enterprise}

Enterprise dapat disebut juga kumpulan organisasi yang memiliki tujuan yang sama dan/atau produk akhir yang sama [2]. enterprise bukan hanya perusahaan yang berfokus kepada profit saja, tetapi organisasi non-profit/nirlaba juga seperti pemerintahan, universitas/sekolah, atau organisasi amal [1]. 


\section{Arsitektur}

Arsitektur adalah rancangan dari segala jenis struktur baik fisik maupun konseptual, baik nyata maupun maya [3]. Arsitektur adalah pengorganisasian yang fundamental dari suatu sistem yang terdiri dari beberapa komponen dan dengan lingkungannya, serta prinsip-prinsip yang digunakan sebagai petunjuk dalam desain dan evolusinya [4].

\section{Arsitektur Enterpise}

Arsitektur Enterprise atau lebih dikenal dengan Enterprise Architecture adalah deskripsi dari misi stakeholder yang di dalamnya termasuk informasi, fungsionalitas/kegunaan, lokasi organisasi dan parameter kinerja. Arsitektur enterprise menggambarkan rencana untuk mengembangkan sebuah sistem atau sekumpulan system [5].

\section{TOGAF}

The Open Group Architecture Framework (TOGAF) adalah kerangka kerja arsitektur yang menyediakan metode dan tools untuk membantu dalam penerimaan, produksi, penggunaan dan pemeliharaan arsitektur enterprise. TOGAF didasarkan pada proses yang berulang-ulang yang didukung oleh best practices dan penggunaan Kembali aset-aset arsitektur yang sudah ada [2].

\section{TOGAF ADM}

TOGAF menyediakan metode terperinci untuk membuat, mengelola, dan menerapkan arsitektur enterprise dan sistem informasi yang disebut Metode Pengembangan Arsitektur (ADM). ADM merupakan generic yang berisikan sekumpulan model arsitektur yang digunakan dan dibuat selama tahap pengembangan arsitektur enterprise [1].

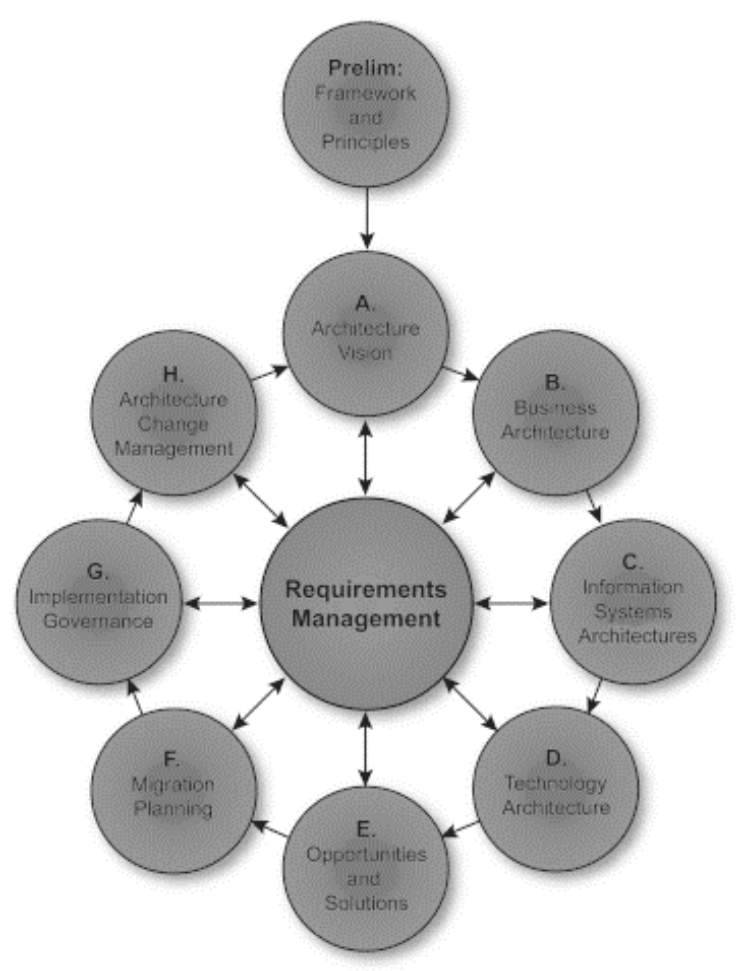

Gambar 1 : TOGAF ADM 


\section{METODE}

Metode Pengumpulan Data

1) Metode Observasi

Observasi dilakukan dengan melihat langsung aktivitas yang berjalan di PT INTI (Persero) pada bulan Maret sampai April yang berlokasi pada Jalan Moch Toha No. 77 Bandung 40253. Hasil observasi yang didapat yaitu profil PT. INTI (Persero), visi dan misi PT. INTI (Persero), proses bisnis yang ada, layanan atau produk yang ditawarkan, serta mengamati layanan teknologi informasi yang digunakan. Observasi dilakukan untuk melihat dan mendapatkan gambaran nyata proses bisnis dan layanan yang ada pada PT. INTI (Persero).

2) Metode Studi Dokumentasi

Metode ini dilakukan dengan mengumpulkan dokumen-dokumen tentang topik pembahasan penelitian. Sumber dokumen ini adalah dokumen resmi perusahaan yang telah disahkan atau draft perusahaan yang belum disahkan. Studi dokumentasi ini mendukung proses evaluasi yang dijelaskan dalam tujuan penelitian.

3) Metode Studi Pustaka

Metode ini dilakukan untuk menambah referensi teori-teori yang dapat menunjang penelitian dengan cara mencari data dan informasi yang berkaitan dengan analisis arsitektur enterprise dan TOGAF ADM dari buku-buku, jurnal-jurnal, situs internet, artikel dan dokumen-dokumen lain. Informasi yang didapatkan diharapkan dapat membantu penelitian ini dalam membuat dan menyusun pembahasan.

B. Metode Analisis Arsitektur Enterprise
Metode yang digunakan untuk menganalisis arsitektur enterprise adalah TOGAF Architecture Development Method (ADM). Langkah pertama untuk mengimplementasikan TOGAF ADM adalah mempersiapkan, yang terdiri dari mengidentifikasi arsitektur yang akan dikembangkan untuk menghasilkan prinsip-prinsip arsitektur yang dibutuhkan. Langkah selanjutnya adalah menentukan strategi arsitektur dan menentukan bagianbagian dari arsitektur yang akan dirancang, seperti: Arsitektur visi, arsitektur bisnis, arsitektur data, arsitektur aplikasi, dan arsitektur teknologi. Metodologi TOGAF ADM yang digunakan penulis terdiri dari 5 tahapan, yaitu::

1) Preliminary Phase

Pada fase preliminary dilakukan persiapan analisis arsitektur enterprise dengan mendefinisikan prinsip-prinsip analisis arsitektur enterprise sebagai acuan dalam pengembangan arsitektur enterprise.

2) Architecture Vision

Pada fase arsitektur visi bertujuan untuk membuat keseragaman padangan mengenai pentingnya perancangan arsitektur enterprise untuk mencapai tujuan dari PT. INTI yang dirumuskan dalam bentuk strategi, serta menentukan ruang lingkup dari arsitektur yang akan dikembangkan.

3) Business Architecture

Pada fase arsitektur bisnis bertujuan untuk mendefinisikan kondisi proses bisnis yang ada, dan actor yang terlibat dalam proses bisnis yang ada.

4) Information System Architecture 
Pada fase arsitektur sistem informasi menentukan bagaimana membangun arsitektur sistem informasi yang meliputi arsitektur data dan arsitektur aplikasi yang ada pada PT. INTI (Persero)

5) Technology Architecture

Pada arsitektur teknologi menggambarkan struktur teknologi yang ada pada PT. INTI (Persero) untuk menunjang operasional sistem informasi.

\section{HASIL DAN PEMBAHASAN}

\section{Preliminary Phase}

Prinsip-prinsip yang akan digunakan sebagai pedoman dalam analisis arsitektur enterprise seperti berikut:

1) Rangka kerja terbuka. Pengembangan arsitektur menggunakan rangka kerja terbuka sehingga memudahkan dalam pemahaman dan pengembangan terbuka.

2) Mudah dipahami. Arsitektur menggambarkan perusahaan secara umum dalam bentuk helicopter view yang mudah dipahami oleh semua pihak terkait.

3) Diperbaharui berkala. Arsitektur akan diperiksa dan diubah secara berkala untuk menjamin mengikuti perkembangan organisasi yang dinamis.

4) Dikembangkan bersama. Arsitektur dengan melibatkan seluruh SDM yang ada, sehingga arsitektur ini adalah milik Bersama dana diterapkan secara gotong royong bersama sama

5) Mengikuti kemampuan organisasi. Arsitektur yang dikembangkan akan diterapkan dengan mengikuti kemampuan perusahaan, baik secara organisasi maupun ekonomi.

6) Harus sesuai. Keputusan arsitektur yang dibuat harus sesuai dengan visi, misi, tujuan, serta proses bisnis yang ada.

\section{Architecture Vision}

1) Visi dan Misi

Visi dari PT. INTI (Persero) adalah Provider in Telco Industry, ICT \& Digital in PT.

Visi Perusahaan sebagaimana dijelaskan di atas akan dicapai melalui misi yang dinyatakan di bawah ini:

- Membangun kompetensi SDM yang unggul serta produktif terutama dalam bidang managed services dan digital services.

- Menciptakan produk dan services yang excellent sesuai dengan kebutuhan pasar dan berdaya saing.

- Meningkatkan sinergi nasional melalui kerja sama dengan BUMN dan swasta.

- Memaksimalkan penggunaan konten lokal dari setiap product dan services yang di-deliver.

2) Analisis Bussines Model Canvas

Business Model Canvas membuat pemodelan bisnis yang akan dicapai oleh perusahaan dengan menunjukan elemen-elemen kunci, yaitu: key partners, key activities value proposition, customer relationships, customer segments, key resource, channels, revenue stream, dan cost. 


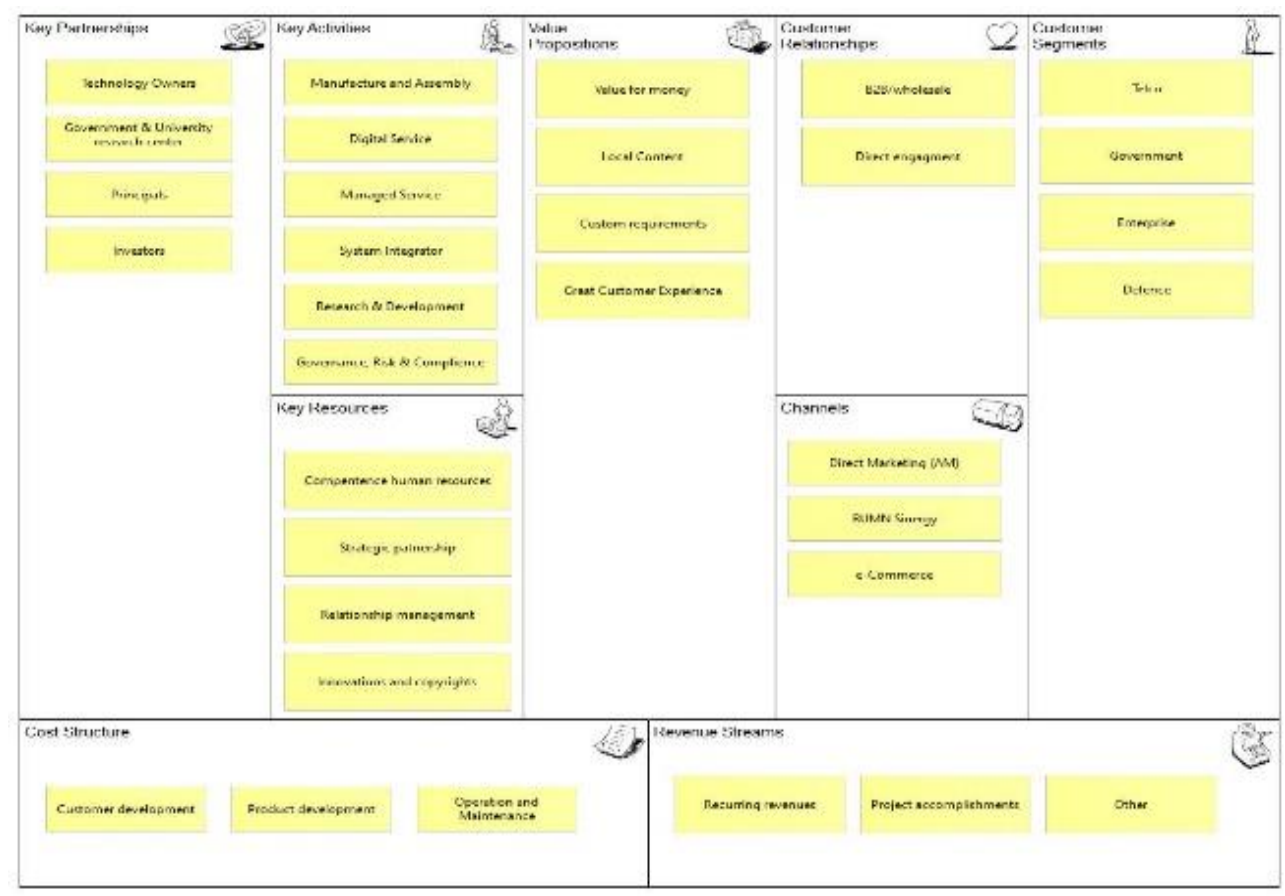

Gambar 2 : Business Model Canvas PT INTI

\section{3) Hasil Analisis PEST}

Analisis PEST merupakan analisis terhadap faktor eksternal yang dapat mempengaruhi kondisi internal dalam perusahaan yang meliputi aspek politik, ekonomi, sosial, dan teknologi. Berikut ini hasil analisis PEST pada PT. INTI (Persero):

Tabel 1 : Analisis PEST PT INTI

\begin{tabular}{|c|c|}
\hline Kategori & Hasil Analisis \\
\hline Politik & $\begin{array}{l}\text { a. Penundaan realisasi Pilkada serentak } 2020 \text { dan terbatasnya } \\
\text { realisasi program pemerintah lainya akibat pandemik Covid- } \\
19 \\
\text { b. Kebijakan TKDN khususnya untuk produk telco semakin } \\
\text { mengerucut untuk dapat direalisasikan, dengan sepakatnya } \\
\text { pelaku sektor telco atas pentingnya industri penyedia telco } \\
\text { dalam negeri } \\
\text { c. Terjadinya deglobalisasi sebagai dampak pandemik }\end{array}$ \\
\hline Ekonomi & $\begin{array}{l}\text { a. Asumsi makro ekonomi RAPBN 2021: pertumbuhan } \\
\text { ekonomi 4,5-5,5\%, inflasi 2-4\%, nilai tukar rupiah } \\
\text { Rp.13.700-Rp. 4.900 per USD, suku Bunga SBN } 10 \text { tahun } \\
\text { 6,29\% - 8,29\% } \\
\text { b. Efek Covid-19, Realisasi Q2 2020, Pertumbuhan ekonomi - } \\
5,32 \% \text {, namun rata rata memperkirakan positif pada TW IV } \\
2020(<1 \%) \\
\text { c. Realisasi pendapatan negara Q2 } 202047,7 \% \text { thd target, turun } \\
\text { 9,8\% yoy. } \\
\text { d. Realisasi ekspor Juli } 20 \text { turun 9,9\% yoy. Impor turun 32,55\% } \\
\text { yoy }\end{array}$ \\
\hline Sosial & $\begin{array}{l}\text { a. Meningkatnya penggunaan internet dan jumlah pelanggan } \\
\text { indihome sebesar 30-40\% dengan kebijakan PJJ dan WFH } \\
\text { b. Peningkatan transaksi e-commerce tertinggi untuk makanan } \\
\text { 10,7x pada bulan April dibandingkan Januari } 2020 \\
\text { c. Melonjaknya jumlah pengguna aplikasi Online meeting pada } \\
\text { Q1 2020, terutama pengguna zoom, skype dan google meet }\end{array}$ \\
\hline
\end{tabular}




\begin{tabular}{|c|c|}
\hline Kategori & \multicolumn{1}{c|}{ Hasil Analisis } \\
\hline Teknologi & a. $\begin{array}{l}\text { Gartner merilis top 10 data \& analiytics tech trends sebagai } \\
\text { dampak pandemic untuk membantu pengambilan keputusan: } \\
\text { AI, decline of dashboard, decision intelligent, X analiytic, } \\
\text { augmented data management, blockchain in data analiytics, } \\
\text { dll. Menunjukkan peningkatan kebutuhan alat penunjang } \\
\text { pengambilan keputusan khususnya pasca pandemik } \\
\text { TOP 3 IoT trends 2020: security, SAAS, data analytics } \\
\text { (LORIOT) }\end{array}$ \\
\hline
\end{tabular}

Sumber: PT INTI 2020

\section{Business Architecture}

1) Organization/Actor Catalog

Organization/Actor Catalog merupakan daftar divisi atau direktorat dan aktor yang ada di PT
INTI dalam menjalankan setiap fungsi dan proses bisnis pada PT. INTI (Persero). Pada PT. INTI (Persero) terdapat 16 unit yang terlibat.

Tabel 2 : Organization/Actor Catalog

\begin{tabular}{|c|c|}
\hline Organization & Actor \\
\hline \multirow{3}{*}{ Direktorat } & Direktur Utama \\
\hline & Direktur Bisnis \\
\hline & Direktur Keuangan \\
\hline \multirow{6}{*}{ Divisi Pemasaran \& Penjualan } & Vice President Pemasaran dan Penjualan \\
\hline & Manajer Penjualan Telco \\
\hline & Manajer Penjualan Pemerintahan Pertahanan \\
\hline & Manajer Penjualan Enterprise Non Telco \\
\hline & Manajer Penjualan Pemerintahan Non Pertahanan \\
\hline & Staf \\
\hline \multirow{6}{*}{ Divisi Produksi \& Layanan Terkelola } & Vice President Produksi dan Layanan Terkelola \\
\hline & Manajer Perencanaan dan Pengendalian Produksi \\
\hline & Manajer Produksi \\
\hline & Manajer Layanan Terkelola \\
\hline & Manajer Purna Jual \\
\hline & Staf \\
\hline \multirow{6}{*}{ Divisi Pengelolaan Produk \& Solusi } & Vice President Pengelolaan Produk dan Solusi \\
\hline & Manajer Pengelolaan Produk Manufacturer Assembly \\
\hline & Manajer Pengelolaan Produk Layanan Terkelola \\
\hline & Manajer Pengelolaan Produk Layanan Digital \\
\hline & Manajer Pengelolaan Produk Sistem Integrator \\
\hline & Staf \\
\hline \multirow{5}{*}{$\begin{array}{l}\text { Divisi Manajemen Proyek \& Jaminan } \\
\text { Kualitas }\end{array}$} & $\begin{array}{l}\text { Vice President Manajemen Proyek dan Jaminan } \\
\text { Kualitas }\end{array}$ \\
\hline & $\begin{array}{l}\text { Manajer Perencanaan dan pengendalian Jaminan } \\
\text { Kualitas Proyek }\end{array}$ \\
\hline & Manajer Manajemen Proyek 1 \\
\hline & Manajer Manajemen Proyek 2 \\
\hline & Staf \\
\hline
\end{tabular}




\begin{tabular}{|c|c|}
\hline Organization & Actor \\
\hline \multirow{7}{*}{ Divisi Pengadaan Niaga \& Mitra Usaha } & Vice President Pengadaan Niaga dan Mitra Usaha \\
\hline & $\begin{array}{l}\text { Manajer Perencanaan dan pengendalian Pengadaan } \\
\text { Niaga }\end{array}$ \\
\hline & Manajer Pengadaan 1 \\
\hline & Manajer Pengadaan 2 \\
\hline & Manajer Manajemen Material \\
\hline & Manajer Kemitraan Niaga \\
\hline & Staf \\
\hline \multirow{7}{*}{$\begin{array}{c}\text { Divisi Teknologi Informasi \& Pengembangan } \\
\text { Produk }\end{array}$} & $\begin{array}{l}\text { Vice President Teknologi Informasi dan } \\
\text { Pengembangan Produk: }\end{array}$ \\
\hline & $\begin{array}{l}\text { Manajer Perencanaan dan Pengendalian Teknologi } \\
\text { lnformasi dan Pengembangan Produk }\end{array}$ \\
\hline & Manajer lnfrastruktur \\
\hline & Manajer Pengembangan Teknologi lnformasi; \\
\hline & Manajer Pengembangan Produk \\
\hline & Kelompok Pengembang. \\
\hline & Staf \\
\hline \multirow{5}{*}{ Divisi Keuangan } & Vice President Keuangan \\
\hline & Manajer Strategi Pendanaan \\
\hline & Manajer Pendanaan Operasional \\
\hline & Manajer Penagihan, Pajak, dan Asuransi \\
\hline & Staf \\
\hline \multirow{6}{*}{ Divisi Akuntansi } & Vice President Akuntansi \\
\hline & $\begin{array}{l}\text { Manajer Evaluasi Kinerja Anak Perusahaan dan } \\
\text { Afiliasi }\end{array}$ \\
\hline & Manajer Akuntansi Keuangan \\
\hline & Manajer Akuntansi Manajemen \\
\hline & Kelompok Ahli Akuntansi \\
\hline & Staf \\
\hline \multirow{5}{*}{ Divisi Manajemen Sumber Daya Manusia } & Vice President Manajemen Sumber Daya Manusia \\
\hline & Manajer Pengembangan Organisasi dan SDM \\
\hline & Manajer Administrasi dan Pelayanan SDM \\
\hline & $\begin{array}{l}\text { Kelompok Ahli Pengembangan Organisasi dan Sistem } \\
\text { SDM }\end{array}$ \\
\hline & Staf \\
\hline \multirow{5}{*}{ Divisi Umum \& Logistik Non Niaga } & Vice President Umum dan Logistik Non Niaga \\
\hline & Manajer Pengadaan Non Niaga \\
\hline & Manajer Umum \\
\hline & Manajer Optimalisasi Properti \\
\hline & Staf \\
\hline \multirow{4}{*}{ Divisi Sekretaris \& Komunikasi Perusahaan } & Vice President Sekretaris dan Komunikasi \\
\hline & Manajer Administrasi Direksi \\
\hline & Manajer Hubungan Masyarakat \\
\hline & Staf \\
\hline
\end{tabular}


ISBN 978-623-92199-2-5

\begin{tabular}{|c|c|}
\hline Organization & Actor \\
\hline \multirow{5}{*}{$\begin{array}{l}\text { Divisi Perencanaan Strategis \& } \\
\text { Pengembangan Usaha }\end{array}$} & $\begin{array}{l}\text { Vice President Perencanaan Strategis \& } \\
\text { Pengembangan Usaha }\end{array}$ \\
\hline & Manajer Strategi Perusahaan \\
\hline & Manajer Pengembangan Usaha \\
\hline & $\begin{array}{l}\text { Kelompok Ahli Perencanaan dan Pengendalian } \\
\text { Strategis }\end{array}$ \\
\hline & Staf \\
\hline \multirow{4}{*}{$\begin{array}{c}\text { Divisi Hukum, Kualitas Manajemen Risiko \& } \\
\text { Tata Kelola }\end{array}$} & $\begin{array}{l}\text { Vice President Hukum, Kualitas, Manajemen Risiko, } \\
\text { dan Tata Kelola }\end{array}$ \\
\hline & Manajer Manajemen Kualitas dan Risiko \\
\hline & Manajer Hukum dan Kepatuhan \\
\hline & Staf \\
\hline \multirow{4}{*}{ Divisi Kerja Sama Operasi } & Vice President Kerja Sama Operasi \\
\hline & $\begin{array}{l}\text { Manajer Perencanaan dan Pengendalian Kerja Sama } \\
\text { Operasi }\end{array}$ \\
\hline & Tim lmplementasi Kerja Sama Operasi \\
\hline & Staf \\
\hline \multirow{4}{*}{ Satuan Pengawas Intern } & Vice President Satuan Pengawasan Intern \\
\hline & Manajer Perencanaan dan Pengendalian Audit \\
\hline & Kelompok Ahli Audit \\
\hline & Staf \\
\hline
\end{tabular}

2) Pemetaan Layanan Bisnis di PT. INTI

Pemetaan Layanan bisnis dimodelkan dengan diagram tree. Bagian atas pada diagram ini adalah layanan bisnis pada PT. INTI. Setiap layanan bisnis memiliki beberapa produk atau jasa. Pada PT. INTI (Persero) memiliki 4 layanan bisnis yang utama yaitu Manufacture And Assembly, Manage Service, Digital Service, dan System Integrator.

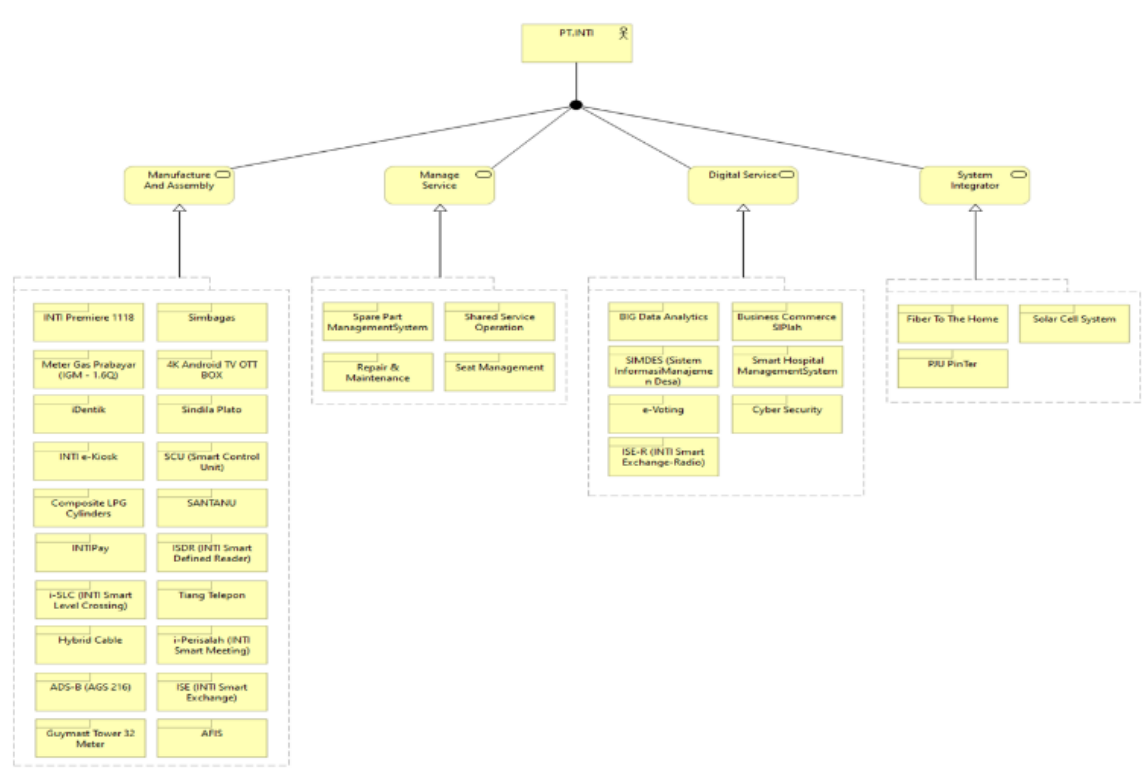

Gambar 3 :Layanan Bisnis PT INTI 
3) General Business Process Diagram

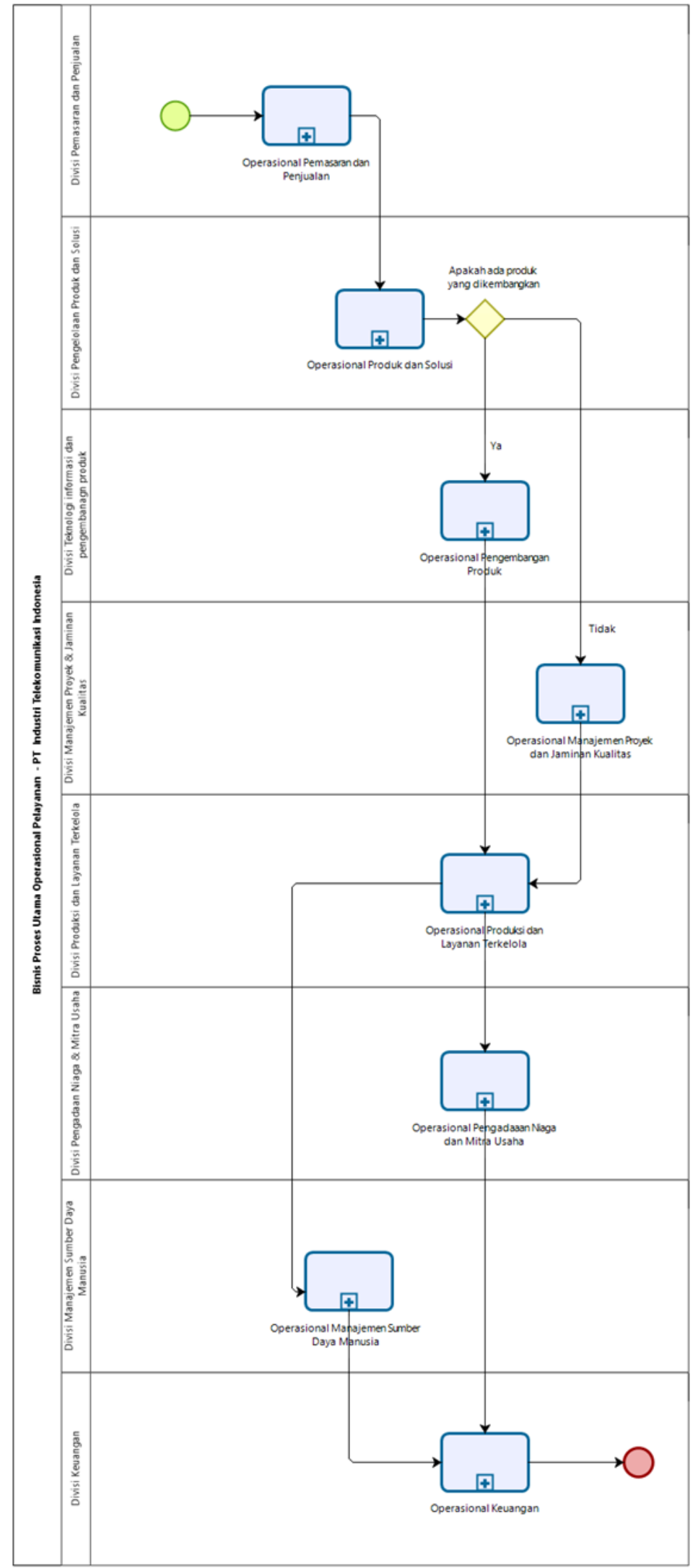

Gambar 4 : Bisnis Proses Utama PT INTI

Prosiding Seminar Sosial Politik, Bisnis, Akuntansi dan Teknik (SoBAT) ke-3 


\section{Information System Architecture}

1) Application Portofolio Catalog

Application portofolio catalog merupakan daftar aplikasi-aplikasi yang ada saat ini di PT.

INTI (Persero), aplikasi-aplikasi yang ada dikategorikan menjadi dua yaitu ERP dan
NON-ERP. Application portofolio catalog membantu untuk mengidentifikasi kebutuhan aplikasi ke depanya dan memberikan informasi terkait aplikasi yang ada baik yang masih dipakai atau yang sudah tidak dipakai.

Tabel 3 : Application Portofolio Catalog

\begin{tabular}{|c|l|l|}
\hline No & \multicolumn{1}{|c|}{ Nama Aplikasi } & Kategori \\
\hline 1 & HCIS & NON-ERP \\
\hline 2 & ESS (Employee Self Service) & NON-ERP \\
\hline 3 & IT - SERVICE & NON-ERP \\
\hline 4 & Helpdesk INTI (Call Center) & NON-ERP \\
\hline 5 & MATMAN & NON-ERP \\
\hline 6 & PROLINE.INTI.CO.ID & NON-ERP \\
\hline 7 & OPEN PROJECT & NON-ERP \\
\hline 8 & PROJECT.INTI.CO.ID & NON-ERP \\
\hline 9 & DEMO.INTI.CO.ID & NON-ERP \\
\hline 10 & E-KATALOG & NON-ERP \\
\hline 11 & E-PROCUREMENT & NON-ERP \\
\hline 12 & SIKUG-PERDIN & NON-ERP \\
\hline 13 & AGENDA & NON-ERP \\
\hline 14 & E-RECRUITMENT & NON-ERP \\
\hline 15 & I-KNOW & NON-ERP \\
\hline 16 & SKI-ONLINE & NON-ERP \\
\hline 17 & PORTAL SIMK3 & NON-ERP \\
\hline 18 & SMART QRM & NON-ERP \\
\hline 19 & DASHBOARD.INTI.CO.ID & NON-ERP \\
\hline 20 & Portal Divisi Hukum & NON-ERP \\
\hline 21 & I-PORTAL & NON-ERP \\
\hline 22 & Website INTI & NON-ERP \\
\hline 23 & SAP-Project System (PS) & ERP \\
\hline 24 & SAP-Material Management (MM) & ERP \\
\hline 25 & SAP-Human Resource (HR) & ERP \\
\hline 26 & SAP-Production Planning (PP) & ERP \\
\hline 27 & SAP-Finance and Controlling (FICO) & ERP \\
\hline
\end{tabular}




\section{Technology Architecture}

1) Technology Standar Catalog

Technology standar catalog digunakan untuk menggambarkan teknologi yang menjadi standar baik itu software atau hardware yang digunakan untuk membantu proses bisnis berjalan.

\section{Tabel 4 : Technology Standar Catalog}

\begin{tabular}{|c|c|}
\hline $\mathrm{NO}$ & Nama \\
\hline 1 & PHP sebagai Standar Bahasa Pemrograman \\
\hline 2 & Codeigniter Sebagai Standar Content Management \\
\hline 3 & SAP sebagai Standar Aplikasi ERP \\
\hline 4 & $\begin{array}{l}\text { Linux Centos } 7.064 \text { Bit atau Ubuntu Server 16.04 64 Bit Sebagai Standar Perangkat Lunak Open } \\
\text { Source Server }\end{array}$ \\
\hline 5 & $\begin{array}{l}\text { Microsoft Windows Server 2008R2 } 64 \text { Bit Sebagai Standar Perangkat Lunak Licensed Operating } \\
\text { System Server }\end{array}$ \\
\hline 6 & Adobe Acrobat Reader untuk Perangkat Lunak Tools \\
\hline 7 & $\begin{array}{l}\text { Browser (Mozilla Firefox, Google Chrome Browser, Netscape Navigator) untuk Perangkat Lunak } \\
\text { Tools }\end{array}$ \\
\hline 8 & Compression (Winrar, 7 Zip) untuk Perangkat Lunak Tools \\
\hline 9 & Anti Virus (Forti Client Endpoint Security, Avast) untuk Perangkat Lunak Tools \\
\hline 10 & $\begin{array}{l}\text { Microsoft Office } 2016 \text { Pro Plus (untuk fungsi Pemasaran, Hukum, Manajemen Proyek, Sales } \\
\text { Engineering dan Penagihan) untuk Perangkat Lunak Produktivitas }\end{array}$ \\
\hline 11 & WPS Office 2016 atau yang terbaru untuk Perangkat Lunak Produktivitas \\
\hline 12 & Ubuntu Desktop 16.04 LTS 64 Bit atau yang terbaru untuk Perangkat Lunak AOD \\
\hline 13 & $\begin{array}{l}\text { Microsoft Windows (Windows } 7 \text { Professional } 64 \text { Bit / Windows } 10 \text { Professional } 64 \text { Bit) untuk } \\
\text { Perangkat Lunak AOD }\end{array}$ \\
\hline 14 & Fortinet VPN (Office VPN Connection) \\
\hline 15 & Team Viewer (End to End Connection) \\
\hline
\end{tabular}

\section{KESIMPULAN}

Berdasarkan hasil pembahasan pada penelitian ini dalam bab sebelumnya, maka dapat ditarik beberapa kesimpulan seperti berikut ini :

PT. INTI (Persero) dalam proses bisnisnya telah memanfaatkan sistem informasi dan teknologi informasi akan tetapi strategi bisnis dan strategi SI/TI belum selaras dengan baik karena masih terdapat masalah di mana dalam pembuatan aplikasi masih bersifat fungsional tidak terencana dengan baik, terdapat juga aplikasi yang berbeda yang memiliki fitur sama dengan database berbeda dan terdapat aplikasi yang tidak digunakan lagi setelah tahap implementasi. Oleh karena itu, pada analisis arsitektur enterprise akan dirancang arsitektur bisnis dan arsitektur sistem informasi untuk memaksimalkan penggunaan SI/TI dan akan dirancang arsitektur teknologi yang akan mendukung pengembangan arsitektur sistem informasi yang sudah dirancang. Diharapkan dengan dirancangnya arsitektur enterprise ini dapat membantu PT. INTI (Persero) dalam mengoptimalkan pemanfaatan SI/TI yang selaras dengan strategi bisnis. 


\section{DAFTAR PUSTAKA}

[1] K. Surendro, "Pengembangan Rencana Induk Sistem Informasi," Informatika, p. 356, 2009.

[2] TOGAF, "TOGAF ( The Open Group)," Group, 2003. https://www.opengroup.org/togaf (accessed Oct. 02, 2020).

[3] M. A. Cook, "Building Enterprise Information Architectures," HewlettPackard Prof. books, 1996, Accessed: Oct. 03, 2020. [Online]. Available: https://dl.acm.org/doi/abs/10.5555/23 5199.

[4] IEEE-SA Standards Board, "IEEE Recommended Practice for Architectural Description of SoftwareIntensive Systems," IEEE Std, vol. 1471-2000, pp. 1-23, 2000, Accessed: Oct. 03, 2020. [Online]. Available: http://citeseerx.ist.psu.edu/viewdoc/su mmary?doi=10.1.1.102.9904.

[5] D. Minoli, "Enterprise architecture A to $\mathrm{Z}$ : Frameworks, business process modeling, SOA, and infrastructure technology," Enterp. Archit. A to Z Fram. Bus. Process Model. SOA, Infrastruct. Technol., pp. 1-482, 2008, doi: 10.1201/9781420013702.

[6] A. Kristanto, "Perancangan Sistem Informasi dan Aplikasinya (Edisi Revisi)," Gava Media, pp. 2-4, 2018, doi:

10.1017/CBO9781107415324.004.

[7] S. Spewak and S. Hill, "Enterprise architecture planning: developing a blueprint for data, applications and technology," QED Publ. Gr., p. 392, 1993, Accessed: Oct. 03, 2020. [Online]. Available: http://dl.acm.org/citation.cfm?id=138 413.

[8] H. Shah and M. El Kourdi, "Frameworks for enterprise architecture," IT Prof., vol. 9, no. 5, pp. 36-41, Sep. 2007, doi: 10.1109/MITP.2007.86.

[9] "Flavonoid - Wikipedia bahasa Indonesia, ensiklopedia bebas," 2019. https://id.wikipedia.org/wiki/Flavonoi $\mathrm{d}$ (accessed Oct. 05, 2020).

[10] "Menganalisa Bisnis Menggunakan Model PEST/PESTEL." https://www.glngirwn.com/blog/anali sis-pest/ (accessed Oct. 28, 2020).

[11] N. Rizky and A. F. Firmansyah, "PERENCANAAN ARSITEKTUR ENTERPRISE MENGGUNAKAN TOGAF ADM VERSI 9 ( Studi Kasus: Bimbel Salemba Group )," Stud. Inform. J. Sist. Inf., vol. 10, no. 1, 2017.

[12] T. Sulandari, "Perancangan Enterprise Architecture Menggunakan Togaf Architecture Development Method (Studi Kasus Pt. Bali Double C)," Univ. Islam Negeri Syarif Hidayatullah Jakarta, Fak. Sains Dan Teknol., vol. 1, 2015. 